\title{
A Comparative pharmacological study on moxidectin and propolis ointment in rabbits naturally infested with Psoroptes cuniculi
}

\author{
M.F. Eldakroury ${ }^{1}\left(\mathbb{D}\right.$ and A.A. Darwish ${ }^{2} \mathbb{D}$ \\ ${ }^{1}$ Department of Pharmacology, Faculty of Veterinary Medicine, Matrouh University, ${ }^{2}$ Animal and Poultry Health \\ Department, Desert Research Center, Cairo, Egypt
}

\begin{tabular}{l} 
Article information \\
\hline Article history: \\
Received August 25, 2020 \\
Accepted January 1, 2021 \\
Available online October 1,2021 \\
\hline Keywords: \\
Moxidectin \\
Propolis \\
Ear mange \\
Rabbits \\
Biochemical parameters \\
\hline Correspondence: \\
A.A. Darwish \\
asmaa vet25@ yahoo.com
\end{tabular}

\begin{abstract}
Ear mange is an annoying problem for all animal breeders including rabbit's breeders. This study aimed to compare the efficacy of moxidectin and $10 \%$ propolis ointment on rabbits infested with Psoroptes cuniculi with especial reference to some related biochemical parameters diagnostic and prognostic value. For this purpose, a total of thirty-two rabbits: 8 non-infested rabbits (control group (CG) and 24 naturally infested rabbits were used. Infested rabbits were equally divided into three groups: 1st group remained without treatment (diseased group (DG)), 2nd group was treated with moxidectin $((0.2 \mathrm{mg} / \mathrm{kg}$ body weight) S/C (MG)). Propolis ointment (10\%) was applied topically to rabbits of the 3rd group (PG) once daily. Ear scrapes and blood samples were taken on 0, 7, 14 and 21 days. The ear scraping was examined microscopically and the biochemical parameters were estimated and statistically analyzed. The results cleared that moxidectin achieved the complete healing (14th day) faster than propolis ointment (21st day), but MG suffered from a significant $(\mathrm{P}<0.05)$ hypoalbuminemia, increased liver and kidney function tests and cortisol levels when compared to PG. Liver and kidney function tests and cortisol yielded good values of the area under the curve, sensitivity \%, specificity\%, likelihood ratio, PPV\%, NPV\%, accuracy rate\% in DG, MG (except creatinine) and PG. The study concluded that propolis had a prominent antipsoroptic effect without inducing hepatic or renal toxicity. Liver and kidney function tests and cortisol may be useful markers for rabbit mange diagnosis and prognosis and following up its treatment.
\end{abstract}

DOI: 10.33899/ijvs.2021.128171.1560, (CAuthors, 2021, College of Veterinary Medicine, University of Mosul. This is an open access article under the CC BY 4.0 license (http://creativecommons.org/licenses/by/4.0/).

\section{Introduction}

Psoroptes cuniculi is the main cause of rabbit's ear mange. It is a worldwide distributed and extensively threats caged rabbits breeding. Although, the disease first stages are non-fatal, but lowered body weights, fertility rates, treatment and labor cost associated with the disease and its control are economic losses can't be neglected $(1,2)$. In addition, the disease complications may be lethal at chronic untreated cases. Moreover, the disease has a zoonotic importance. The major clinical signs of ear mange infestation include the presence of waxy material in external ear mixed with crusts, pain, pruritus, ulcer, hemorrhages, head shaking, scratching, and loss of body weight $(2,3)$. Ivermectins are the first choice for rabbit mange treatment. Among them, moxidectin which is a second-generation macrocyclic lactone. It is a parasiticide active against a wide range of internal and external parasites (4). Unfortunately, macrocyclic lactone is not currently recommended for use in rabbits in many parts of the world as resistance (5), toxicity and environmental contamination and persistence (6). Interest is developing to use biocompatible products for external parasites in rabbits (7). Propolis is a natural resinous mixture produced by honeybees. Propolis means in Greek, entrance to the community this refers to its role in hive defense. Another name of propolis is bee glue due to its waxy nature and 
mechanical properties, bees use it for building or repairing hives and for sealing openings and cracks and smoothing out the internal walls (8). It was used in medicine by Greek and Roman for its antipyretic, antiseptic and wound healing propriety (9). It is a natural remedy for burns, sore throat, stomach ulcer, upper respiratory tract infections, common cold, and dermatological preparations for wound healing (10). Furthermore, it is effective in the treatment of dermatophytosis (11) and sarcoptic mange (6).

This work was conducted to study using $10 \%$ propolis ointment as an alternate to moxidectin in ear mange treatment with especial reference to the value of proteingram, liver and kidney function tests and cortisol in rabbit's ear mange diagnosis and prognosis and monitoring of the suggested therapeutic programs.

\section{Materials and methods}

This study was carried out according to the ethical approval of Animal and Poultry Health Department, Desert Research Center (DRC), Cairo, Egypt.

\section{Rabbits}

Twenty-four Rabbits (average body weight $2.45-2.90$ $\mathrm{kg}$ ) had a history of anorexia, scratching, shaking their heads and ear and presence of crusty material in the ear canal. Microscopical examination of the lesions revealed that they were infested by with Psoroptes cuniculi. These rabbits had not been previously treated with any anti-acariasis drug. Eight non-infested rabbits (normal appetite, clean ear canal, no signs of irritation or restlessness), were used as a control group (CG). The other infested rabbits were divided into three equal groups each of 8 rabbits (according to body weight- extend of infection). The $1^{\text {st }}$ one (DG) was used as diseased group, group $2(\mathrm{MG})$ received a single dose of moxidectin $(0.2 \mathrm{mg} / \mathrm{kg}$ body weight $) \mathrm{S} / \mathrm{C}$. Propolis was applied topically to the rabbits of group 3 (PG) once daily. They were kept in individual cages, fed a balanced pelleted ration and clean source of water and libitum during the experimental period. All measures were performed to avoid re-infestation from the environment, rabbits were kept under observation (for clinical signs of mange infestation and medication toxicity). Ear scrapings were taken and examined microscopically under low power magnification according to Ulutas et al. (12) on $0^{\text {th }}, 7^{\text {th }}, 14^{\text {th }}$ and $21^{\text {st }}$ day.

\section{Drugs}

CYDECTIN $^{\circledR}$ (Contains $10 \mathrm{mg}$ moxidectin $/ \mathrm{ml}$ ) is a product of Boehringer Ingelheim. 10\% Propolis ointment was prepared according to Sanchez et al. (13) with some modifications.

\section{Sampling}

Blood samples were collected from ear vein of all rabbits at $0^{\text {th }}, 7^{\text {th }}, 14^{\text {th }}$ and $21^{\text {st }}$ day in clean sterilized centrifuge tubes without anticoagulant. The blood allowed to coagulate and the serum was collected and preserved at $-20{ }^{\circ} \mathrm{C}$ for determination of some biochemical parameters. Total protein (TP), albumin (Alb), liver enzymatic activity (aspartate aminotransferase (AST), Alanine aminotransferase (ALT)), kidney function tests (urea, creatinine $(\mathrm{Cr})$ ) were determined spectrophotometrically by using Biodiagnostic company ${ }^{\circledR}$ commercial kits, Cairo, Egypt. While, serum cortisol levels were evaluated using commercial, coated tube radioimmunoassay kits, Pantex, Santa Monica, CA. Serum globulin (Glob) concentrations were obtained by subtracting the value of albumin from the corresponding value of total protein. A/G ratio by division of albumin on the corresponding globulin value.

\section{Statistical analysis}

SPSS program version 24 was used to compare between means of different statistical parameters (one-way ANOVA test), estimate the post-hoc differences between means (a multiple comparison Tukey's HSD test) and determine correlations between the selected parameters (Pearson's simple correlation test). A difference was considerable significant at $\mathrm{P}<0.05$. - Graph pad prism version 5 program was used to evaluate the area under the curve (AUC), cut off points, sensitivity\%, specificity\% and likelihood ratio (LR) for the estimated parameters in DG compared to CG and in MG and PG (before and after the treatment). The positive predictive value (PPV), negative predictive value (NPV) and accuracy rate for them were calculated according the next equations; $\mathrm{PPV}=$ true positive $\div$ total positive $\times 100 ; \mathrm{NPV}=$ true negative $\div$ total negative $\times 100$; Accuracy rate $=$ (true positive + true negative $) \div$ total population $\times 100$.

\section{Results}

According to the obtained data, the clinical signs intense increased along the experiment in DG. At $21^{\text {st }}$ day, the lesions became more prominent and diffuse and the microscopical examination showed a larger number of living mites (P. Cuniculi) in DG. In accordance, the biochemical parameters of DG (compared to CG) displayed a significant increase in total protein and globulin concentrations at $0^{\text {th }}$ day then TP significantly decreased at $7^{\text {th }}, 14^{\text {th }}$ and $21^{\text {st }}$ days, while Glob levels non-significantly changed at $7^{\text {th }}$ day and significantly decreased at $14^{\text {th }}, 21^{\text {st }}$ days. On the other hand, a significant decline was observed in albumin concentrations at $0^{\text {th }}, 7^{\text {th }}, 14^{\text {th }}$ and $21^{\text {st }}$ days. $\mathrm{A} / \mathrm{G}$ ratio significantly reduced at $0^{\text {th }}, 7^{\text {th }}$ days then significantly elevated at $14^{\text {th }}$ and $21^{\text {st }}$ days. A significant increase was also detected in the liver enzymatic activity (AST, ALT), kidney function tests (urea, Cr) and cortisol concentrations at $0^{\text {th }}, 7^{\text {th }}, 14^{\text {th }}$ and $21^{\text {st }}$ days (Figure 1 and 2).

On contrary, a marked gradual improvement of mange clinical signs and a prominent regression of lesions intense, were noticed in both treated groups (MG and PG) from $7^{\text {th }}$ day post-treatment till the end of the experiment. 
Microscopically, a gradual decline of living mites count was observed in MG and PG compared to $0^{\text {th }}$ day.

By $21^{\text {st }}$ day, all treated rabbits recovered completely and clinical signs disappeared and ear scrapes were clean (no living mites). In turn, the above mentioned parameters levels noticeably increased or decreased in $\mathrm{MG}$ and $\mathrm{PG}$ till approaching the CG levels (non-significantly changed with $\mathrm{CG}$ ). TP returned to CG levels in MG and PG at $7^{\text {th }}$ day, Alb in PG at $21^{\text {st }}$ day, $\mathrm{A} / \mathrm{G}$ ratio in MG at $14^{\text {th }}$ day and in PG at $21^{\text {st }}$ day, Glob in MG at $14^{\text {th }}$ day. While, MG recorded a significant decrease in $\mathrm{Alb}$ at $7^{\text {th }}, 14^{\text {th }}$ and $21^{\text {st }}$ days and in $\mathrm{TP}$ concentrations at $14^{\text {th }}$ day (in relation to CG). Glob levels significantly increased in PG compared to $\mathrm{CG}$ at $7^{\text {th }}, 14^{\text {th }}$ and $21^{\text {st }}$ days (Figure 1). Liver and kidney function tests and cortisol concentrations decreased towards CG levels, they non-significantly changed with CG at $7^{\text {th }}$ day for ALT, AST, $\mathrm{Cr}$, cortisol in PG, at $14^{\text {th }}$ day for urea in PG and ALT, urea in $\mathrm{MG}$, and at $21^{\text {st }}$ for AST, cortisol in MG but $\mathrm{Cr}$ significantly increased till the end of the experiment in MG compared to CG (Figure 2).

The comparison between MG and PG exhibited that: the lesions regression was faster in rabbits treated with moxidectin at $14^{\text {th }}$ day, then rabbits treated with $10 \%$ Propolis ointment at $21^{\text {st }}$ day. While, a significant reduction in Alb at $7^{\text {th }}, 14^{\text {th }}$ and $21^{\text {st }}$ day and TP at $14^{\text {th }}$ day was depicted in MG. MG also showed a significant increase in AST at $14^{\text {th }}$ day, in ALT, urea, cortisol at $7^{\text {th }}, 14^{\text {th }}$ day, in $\mathrm{Cr}$ at $7^{\text {th }}, 14^{\text {th }}$ and $21^{\text {st }}$ day. In contrast, Glob significantly elevated in PG at $14^{\text {th }}$, $21^{\text {st }}$ days (Figures 1 and 2).

In connection to the estimated biochemical parameters importance in the disease diagnosis and monitoring the diseased rabbits response to the two studied proposals, table 1 clarified that AST, ALT, urea, $\mathrm{Cr}$ and cortisol yielded high values of AUC in DG, MG (except $\mathrm{Cr}$ ) and PG with acceptable values of sensitivity\%, specificity\%, LR (moderate to high), PPV\%, NPV\% and accuracy rate\% along the experiment (Table 2).
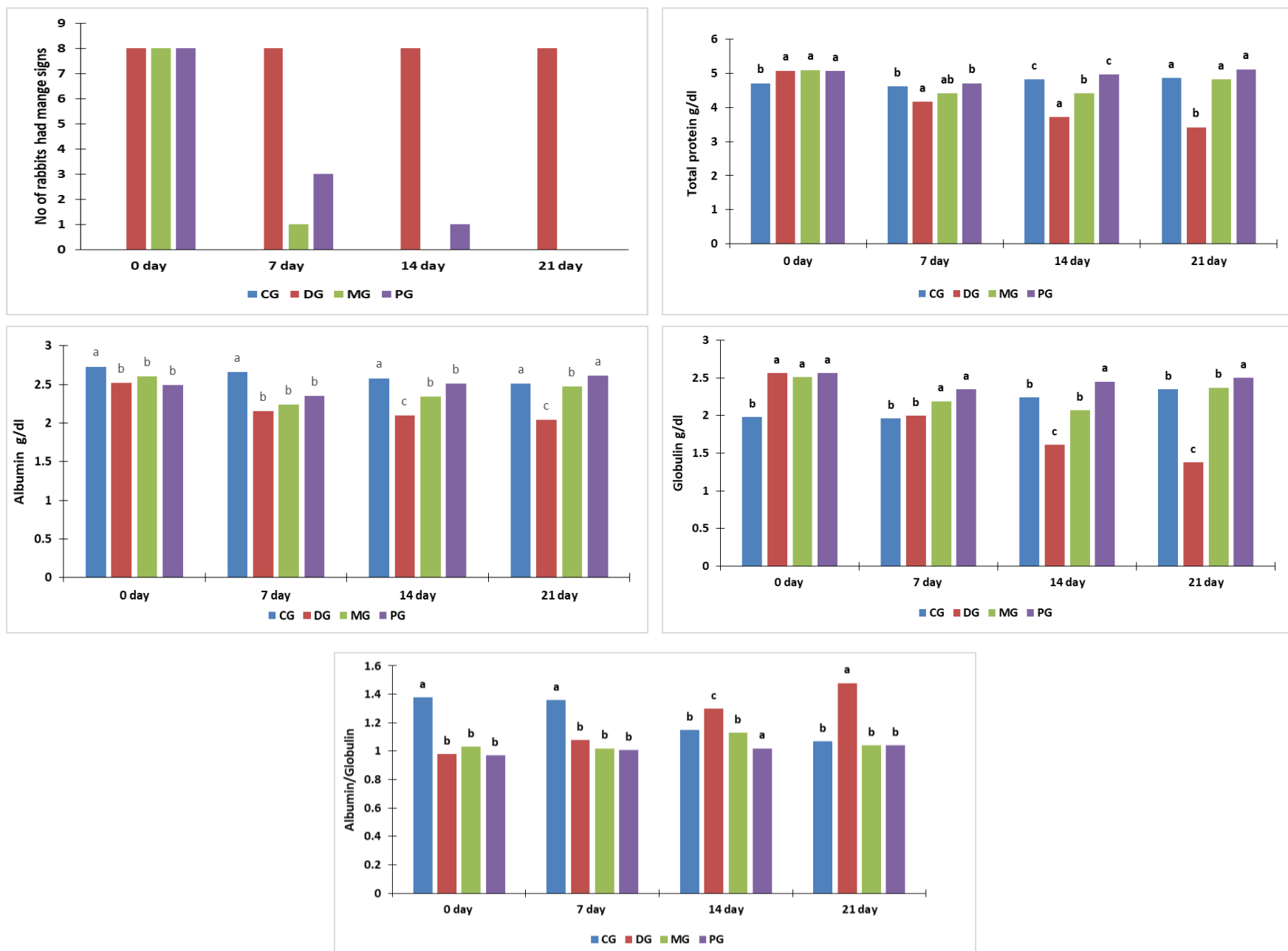

Figure 1: Number of rabbits showing clinical signs and serum levels of protein profile in the studied groups (N=8). Columns bearing different letters for the same day, differ significantly $(\mathrm{P}<0.05)$. CG: control group, DG: diseased group, MG: moxidectin group, PG: propolis group. 

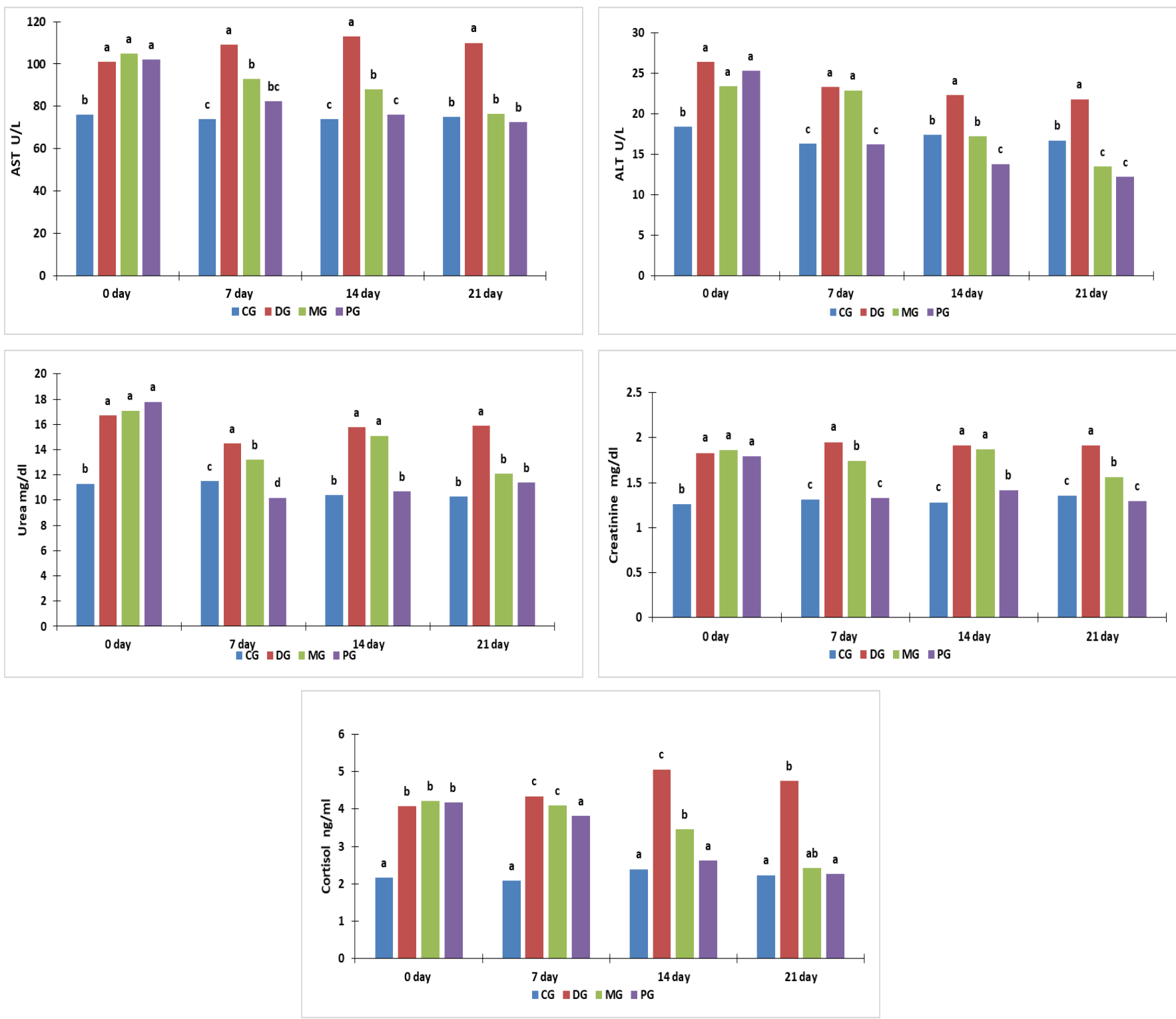

Figure 2: serum levels of liver and kidney functions tests and cortisol in the studied groups $(\mathrm{N}=8)$. Columns bearing different letters for the same day, differ significantly $(\mathrm{P}<0.05)$. CG: control group, DG: diseased group, MG: moxidectin group, PG: propolis group.

\section{Discussion}

P. cuniculi infestation is a serious problem, still annoying all rabbit's breeders all over the world. It reduces animal productivity and may cause death in chronic cases (1-3). In addition, it affects critically on the proteinogram of the diseased rabbits. This was indicated in the current research as well as previous researches by the prominent hyperglobulinemia and subordinate hyperproteinemia and decreased $A / G$ ratio detected in DG at $0^{\text {th }}$ day $(14,15)$. Whereas, the presence of the ear mites with their irritating effect and antigenic proteins stimulate various immune proteins synthesis (immuoglobulins) in order to control the infestation and protect the host $(14,15)$. The hypoglobulinemia and hypoproteinemia recorded later in DG were attributed to the disease development and subsequent anorexia and shortage of the available amino acids which are the basic units of protein synthesis $(14,15)$. A corresponding hypoalbuminemia was noted in DG along the experiment, as the host body gives the priority for the immune protein synthesis on expanse of any other proteins (14-16). No doubt, this fluctuation between albumin and globulin levels resulted in shifting $\mathrm{A} / \mathrm{G}$ from decline at $7^{\text {th }}$ day to increase at $14^{\text {th }}$ and $21^{\text {st }}$ day in DG. 
Table 1: Area under the curve (AUC), cut off points, sensitivity \%, specificity \%, Likelihood Ratios (LR), PPV\%, NPV\%, accuracy rate\% in DG, MG and $\mathrm{PG}$

\begin{tabular}{|c|c|c|c|c|c|c|c|c|c|}
\hline Parameters & Group & AUC & Cut off points & Sensitivity & Specificity & LR & PPV & NPV & Accuracy rate \\
\hline \multirow{3}{*}{$\mathrm{TP}(\mathrm{g} / \mathrm{dl})$} & DG & 0.77 & 4.17 & $58.33 \%$ & $91.67 \%$ & 7 & $87.5 \%$ & $68.75 \%$ & $75 \%$ \\
\hline & MG & 0.74 & 4.86 & $66.67 \%$ & $66.67 \%$ & 2 & $66.67 \%$ & $66.67 \%$ & $66.67 \%$ \\
\hline & PG & 0.56 & 5.00 & $55.56 \%$ & $66.67 \%$ & 1.67 & $62.50 \%$ & $60.00 \%$ & $61.11 \%$ \\
\hline \multirow{3}{*}{ Alb (g/dl) } & DG & 0.84 & 2.30 & $66.67 \%$ & $91.67 \%$ & 8 & $88.89 \%$ & $73.33 \%$ & $79.17 \%$ \\
\hline & MG & 0.64 & 2.48 & $66.67 \%$ & $66.67 \%$ & 2 & $66.67 \%$ & $66.67 \%$ & $66.67 \%$ \\
\hline & PG & 0.54 & 2.55 & $55.56 \%$ & $44.44 \%$ & 1 & $50 \%$ & $50 \%$ & $50 \%$ \\
\hline \multirow{3}{*}{ Glob (g/dl) } & DG & 0.68 & 1.79 & $58.33 \%$ & $91.67 \%$ & 7 & $87.50 \%$ & $68.75 \%$ & $75 \%$ \\
\hline & MG & 0.83 & 2.35 & $55.56 \%$ & $88.89 \%$ & 5 & $88.33 \%$ & $66.67 \%$ & $72.22 \%$ \\
\hline & PG & 0.65 & 2.50 & $66.67 \%$ & $66.67 \%$ & 2 & $66.67 \%$ & $66.67 \%$ & $66.67 \%$ \\
\hline \multirow{3}{*}{$\mathrm{A} / \mathrm{G}$} & DG & 0.54 & 1.07 & $33.33 \%$ & $91.67 \%$ & 4 & $80 \%$ & $57.89 \%$ & $62.50 \%$ \\
\hline & MG & 0.79 & 1.03 & $66.67 \%$ & $66.67 \%$ & 2 & $66.67 \%$ & $66.67 \%$ & $66.67 \%$ \\
\hline & PG & 0.65 & 0.99 & $88.89 \%$ & $55.56 \%$ & 2 & $66.67 \%$ & $83.33 \%$ & $72.22 \%$ \\
\hline \multirow{3}{*}{ AST (U/L) } & DG & 1 & 83.75 & $100 \%$ & $91.67 \%$ & 12 & $92.31 \%$ & $100 \%$ & $95.83 \%$ \\
\hline & MG & 0.85 & 91.95 & $66.67 \%$ & $88.89 \%$ & 6 & $85.71 \%$ & $72.73 \%$ & $77.78 \%$ \\
\hline & PG & 0.98 & 90.60 & $100 \%$ & $88.89 \%$ & 9 & $90 \%$ & $100 \%$ & $94.44 \%$ \\
\hline \multirow{3}{*}{$\mathrm{ALT}(\mathrm{U} / \mathrm{L})$} & DG & 1 & 18.57 & $91.67 \%$ & $91.67 \%$ & 12 & $92.31 \%$ & $100 \%$ & $95.83 \%$ \\
\hline & MG & 0.91 & 21.98 & $77.78 \%$ & $88.89 \%$ & 7 & $87.50 \%$ & $80 \%$ & $83.33 \%$ \\
\hline & PG & 1 & 21.58 & $100 \%$ & $88.89 \%$ & 9 & $90 \%$ & $100 \%$ & $94.44 \%$ \\
\hline \multirow{3}{*}{$\begin{array}{l}\text { Urea } \\
(\mathrm{mg} / \mathrm{dl})\end{array}$} & DG & 0.97 & 13.08 & $91.67 \%$ & $91.67 \%$ & 11 & $91.67 \%$ & $91.67 \%$ & $91.67 \%$ \\
\hline & MG & 0.93 & 15.57 & $88.89 \%$ & $88.89 \%$ & 8 & $88.89 \%$ & $88.89 \%$ & $88.89 \%$ \\
\hline & PG & 1 & 14.79 & $100 \%$ & $88.89 \%$ & 9 & $90 \%$ & $100 \%$ & $94.44 \%$ \\
\hline \multirow{3}{*}{$\mathrm{Cr}(\mathrm{mg} / \mathrm{dl})$} & DG & 1 & 1.47 & $100 \%$ & $91.67 \%$ & 12 & $92.31 \%$ & $100 \%$ & $95.83 \%$ \\
\hline & MG & 0.65 & 1.78 & $66.67 \%$ & $66.67 \%$ & 2 & $66.67 \%$ & $66.67 \%$ & $66.67 \%$ \\
\hline & PG & 1 & 1.6 & $100 \%$ & $88.89 \%$ & 9 & $90 \%$ & $100 \%$ & $94.44 \%$ \\
\hline \multirow{3}{*}{$\begin{array}{l}\text { Cortisol } \\
(\mathrm{ng} / \mathrm{ml})\end{array}$} & DG & 1 & 2.72 & $100 \%$ & $91.67 \%$ & 12 & $92.31 \%$ & $100 \%$ & $95.83 \%$ \\
\hline & MG & 0.81 & 3.55 & $55.56 \%$ & $88.89 \%$ & 5 & $83.33 \%$ & $66.67 \%$ & $72.22 \%$ \\
\hline & PG & 0.89 & 3.54 & $77.78 \%$ & $88.89 \%$ & 7 & $87.50 \%$ & $80 \%$ & $83.33 \%$ \\
\hline
\end{tabular}

DG: diseased group, MG: moxidectin group, PG: propolis group. TP: Total protein, Alb: Albumin, Glob: Globulin, A/G: Albumin/Globulin ratio, AST: Aspartate aminotransferase, ALT: Alanine aminotransferase, Cr: Creatinine. AUC $=0.5-0.65$ (useless marker), AUC $=0.7-0.85$ (good marker), $\mathrm{AUC}=0.86-1$ (with satisfactory sensitivity and specificity: excellent marker). $\mathrm{LR}=0.5-5$ : low; $\mathrm{LR}=5-10$ : moderate; $\mathrm{LR}>10$ : high.

Table 2: The correlation between the numbers of rabbits had clinical signs of Psoroptes mange infestation (No) and the estimated biochemical parameters along the experiments $($ Pearson's correlation test, values $=r)$

\begin{tabular}{cc}
\hline Parameters & No \\
\hline TP & -0.292 \\
Alb & -0.305 \\
Glob & -0.284 \\
A/G & 0.305 \\
AST & $0.900^{*}$ \\
ALT & $0.826^{*}$ \\
Urea & $0.761^{*}$ \\
Cr & $0.673^{*}$ \\
Cortisol & $0.814^{*}$ \\
\hline
\end{tabular}

Statistical significance of correlations was recorded at $\mathrm{P}<0.05$. * mean a significant difference.
Additionally, the ascending increased liver and kidney function test values and hypercortisolemia noted along this experiment in DG, elucidated that the psoroptic mite infestation in rabbits is extremely connected with hepatic and renal injury and advanced degree of stress. These alterations were mainly attributed to the mite's toxic excretory products and its irritating effect. Logically, this hepatic damage took apart in the former hypoalbuminemia, as the liver is the major site of albumin formation $(17,18)$.

Regarding the studied drugs effect, both drugs controlled the disease clinical signs, reduced the number of living mites, acted on lesion regression and subsequently decreased the anorexia, irritation, mite's toxic products and stress related to the disease in both treated groups $(6,19,20)$. Sequentially, the above-described biochemical alterations were corrected in MG and PG.

These findings mimicked many authors views, who mentioned the curative effect of moxidectin against $P$. cuniculi infestation, either subcutaneously injected, topically 
or orally administrated (18-20). It mainly acts through binding to receptors that increase membrane permeability to chloride ions. Thus the electrical activity of nerve cells in nematodes and muscle cells in arthropods is inhibited, the parasites become paralyzed and dead. It also augments the release of the inhibitory neurotransmitter, GABA at presynaptic neurons (19-22). Furthermore, high lipophilicity of moxidectin accounts for a wide tissue distribution. Thus, it massively deposits in fat tissue and accumulates on the skin for long periods. This may explain why only a single topical dose was effective to control mite's different stages in mice (eggs, larvae, adult fur mites) (19-22) and approves its excellent efficacy against different ectoparasites (21).

On the other hand, the topical application of $10 \%$ propolis ointment efficient effect, against different types of mange (Sarcoptic and Psoroptic) in rabbits, was prior recorded after 10-15 days (6) or 3 days (23). Variations in time required for complete reduction of mite lesions may be depend on severity of the infestation and the hygienic measures which may have played a role in re-infestation.

The comparison between the two protocols revealed that: moxidectin was faster than $10 \%$ propolis ointment in achieving the complete recovery at $14^{\text {th }}$, but unfortunately it had a hepatotoxic effect. This was represented in the current data by the detected hypoalbuinema in MG at $7^{\text {th }}, 14^{\text {th }}, 21^{\text {st }}$ day and consequent hypoproteinemia at $14^{\text {th }}$ day (in relation to CG or/and PG). Obviously, the higher activity of liver enzymes in MG than PG and their delaying in reaching CG values, confirmed its hepatotoxicity effect $(24,25)$. In addition, the higher urea and creatinine concentrations recorded in MG than PG till $21^{\text {st }}$ day pointed to urea and creatinine retention due to the moxidectin damaging effect on the renal glomeruli (26). Moreover, skin corrosion and irritation induced by its injection hindered cortisol levels correction in MG till $21^{\text {st }}$ day, while it was corrected in PG since $7^{\text {th }}$ day (27). It worth to mention that, although $10 \%$ propolis ointment had no side effects on liver and kidney and associated with a low degree of stress, its daily topical medications into ear canal is much more laborious and timeconsuming especially for large number of infested animals. It also caused a little hyperglobulinemia in PG continued to the $21^{\text {st }}$ day, because of the late resolution of lesions in some rabbits in PG. Concerning the measured parameters value in the disease detection and the two therapeutic programs monitoring: the data of table (1 and 2) nominated AST, ALT, urea, $\mathrm{Cr}$ and cortisol as good markers for mange infestation in rabbit and following up its treatment. Similar opinion was suggested before by Metwally et al. (14).

\section{Conclusion}

It could be concluded that, although propolis was less effective against psoroptic mange of rabbits as compared to moxidectin, it had no adverse effect on the liver and kidney of the treated rabbits. Propolis could be used as an alternative to other traditional medicines. However, it is worth emphasizing that, treatment of mangy rabbits must be accompanied by strict hygiene based on constant cleaning and disinfection of hutches and cages. Liver and kidney function tests and cortisol may be helpful markers for mange infestation in rabbits and therapeutic programs evaluation.

\section{Acknowledgments}

Stuff members of stuff members of animal and poultry health department, DRC, Cairo, Egypt.

\section{Conflict of interest}

There is no conflict of interest.

\section{References}

1. Shakya M, Singh M, Jayraw AK. Clinical management of sarcoptic mange in rabbits. Ind J Vet Sci Biotech. 2018;14(1)1-10. Doi: 10.21887/ijvsbt.v14i1.13004

2. Ogolla KO, Chebet J, Waruiru RM, Gathumbi PK, Okumu PO, Aboge GO. Efficacy of ivermectin, liquid paraffin, and carbaryl against mange of farmed rabbits in central Kenya. J Trop Med. 2019;5092845:1-8. Doi: $10.1155 / 2019 / 5092845$

3. Mustafa BH. Detection on ectoparasites on small ruminants and their impact on the tanning industry in Sulaimani province. Iraqi J Vet Sci. 2019;3(1):303-309. Doi: 10.33899/ijvs.2019.162995

4. Batiha GES, Beshbishy AM, Tayebwa DS, Adeyemi OS, Yokoyama M, Igarashi I. Evaluation of the inhibitory effect of ivermectin on the growth of Babesia and Theileria parasites in vitro and in vivo. Trop Med Health. 2019;47(42):1-10. Doi: 10.1186/s41182-019-0171-8

5. Sutherland IA, Leathwick DM. Anthelmintic resistance in nematode parasites of cattle a global issue. Trends Parasitol. 2011;27:176-81. Doi: 10.1016/j.pt.2010.11.008

6. Metwally DM. The curative efficacy of Propolis on rabbits naturally infested with mite. EVMSPJ. 2015;11:83-87. Doi: 10.21608/evmspj.2015.37939

7. Shahatha SS. Epidemiological, diagnostic and therapeutic study for mange in sheep of Anbar province - Iraq. Iraqi J Vet Sci. 2020;34(1):17. Doi: $10.33899 /$ ijvs.2020.163587.

8. Hassan MG, Abdullah TA. The effect of Propolis addition to broiler feeds on some blood biochemical parameters and intestinal flora. Iraqi J Vet Sci. 2020;34(1):29-35. Doi: 10.33899/ijvs.2019.125483.1015

9. Bankova V, Popova M, Trusheva B. Propolis volatile compounds: Chemical diversity and biological activity: A review. Chem Cent J. 2014;8:28. [available here]

10. Wagh VD. Propolis: A wonder bees product and its pharmacological potentials. Adv Pharmacol Sci. 2013;13:1-11. Doi: $10.1155 / 2013 / 308249$

11. Sforcin JM, Bankova V. Propolis:Is there a potential for the development of new drugs? J Ethnopharmacol. 2011;133:253-260. Doi: 10.1016/j.jep.2010.10.032

12. Ulutas B, Voyvoda H, Bayramli, G Karagenc Efficiency of topical administration of eprinomectin for treatment of ear mite infestation in six rabbits. Vet Dermatol. 2005;16:334-337. Doi: 10.1111/j.13653164.2005.00464.X

13. Sanchez TA, Garcia PA, Zamora CI, Martinez MA, Valencia VP, Orozco AL. Use of propolis for topical treatment of dermatophytosis in dog. Op J Veter Med. 2014;4:239. Doi: 10.4236/ojvm.2014.410028

14. Metwally DM, Al-Olayan EM, Alshalhoop RA, Eisa SA. Biomarkers as predictive tools to test the in vivo anti-sarcoptic mange activity of propolis in naturally infested rabbits. Biosci Rep. 2018;38:BSR20180874. Doi: 10.1042/BSR20180874

15. Panigrahi PN, Mohanty BN, Gupta AR, Patra RC, Dey S. Concurrent infestation of notoedres, sarcoptic and psoroptic acariosis in rabbit and 
its management. J Parasit Dis. 2016;40(3):1091-1093. Doi: 10.1007/s12639-014-0631-3

16. Jana PS, Guha C, Saha SB, Khurana R. Clinicopathological and therapeutic studies on natural Psoroptic acariosis in rabbits. Bangl J Vet Med. 2004;2(2):155-158. Doi: 10.3329/bjvm.v2i2.2561

17. Moonarmart W, Tansakul M, Kiewsiri C, Watanaboonchai R, Somrith $\mathrm{W}$, Yinharnmingmongkol C, Tunhikorn M. Haematological response in the treatment of naturally acquired ectoparasite infestation in rabbits. World Rabbit Sci. 2018;26:313-320. Doi: 10.4995/wrs.2018.9823

18. Hallal-Calleros C, Morales-Montor J, Vazquez-Montiel JA, Hoffman KL, Nieto-Rodríguez A, Flores-Pérez FI. Hormonal and behavioral changes induced by acute and chronic experimental infestation with Psoroptes cuniculi in the domestic rabbit Oryctolagus cuniculus. Parasite Vect. 2013;6:361-371. Doi: 10.1186/1756-3305-6-361

19. Rambozzi L, Rossi L, Min AR, Osella L, Bellardi S, Marchetti R, Pollicino P. Efficacy and safety of topical eprinomectin to control Myocoptes musculinus infestation in mice. Braz J Vet Parasitol Jaboticabal. 2014;23(1):244-247. Doi: 10.1590/S1984-29612014024

20. Wagner R, Wendlberger U. Field efficacy of moxidectin in dogs and rabbits naturally infested with Sarcoptes spp., Demodex spp. and Psoroptes spp. mites. Vet Parasitol. 2000;93:149-158. Doi: 10.1016/S0304-4017(00)00357-5.

21. Bernigaud C, Fang F, Fischer K, Lespine A, Aho LS, Dreau D, Kelly A, Sutra JF, Moreau F, Lilin T, Botterel F, Guillot J, Chosidow O. Preclinical study of single-dose moxidectin, a new oral treatment for scabies: Efficacy, safety, and pharmacokinetics compared to two-dose ivermectin in a porcine model. PLoS Negl Trop Dis. 2016;10(10):e0005030. Doi: 10.1371/journal.pntd.0005030

22. Lifschitz A, Virkel G, Imperiale F, Sutra JF, Galtier P, Lanusse C, Alvinerie M. Moxidectin in cattle: Correlation between plasma and target tissues disposition. J Vet Pharmacol Ther. 1999;22:266-273 . Doi: $10.1046 / j .1365-2885.1999 .00222 . x$

23. Abd El-Aal AM. Effect of propolis on mange in rabbits. EVMSPJ. 2005;II(1):293-304. [available here]

24. Ashang BU. Effect of therapeutic and toxic doses of ivermectin (Mectizan) on total serum proteins and hepatic enzymes of wistar albino rats. Int J Biol Chem. 2009;3:142-147. Doi: 10.3923/ijbc.142.147

25. Magdy BW, Mohamed FE, Amin AS, Rana SS. Ameliorative effect of antioxidants (vitamins $\mathrm{C}$ and $\mathrm{E}$ ) against abamectin toxicity in liver, kidney and testis of male albino rats. J Basic Appl Zool. 2016;77:6982. Doi: $10.1016 /$ j.jobaz.2016.10

26. Arise RO, Malomo SO. Effects of ivermectin and albendazole on some liver and kidney function indices in rats. Afr $\mathrm{J}$ Biochem Res. 2009;3:190-197. [available here]

27. Orihuela A, Aguirre V, Hernandez C, Flores-Perez I, Vazquez P. Breaking down the effect of electro-ejaculation on the serum cortisol response, heart and respiratory rates in hair sheep (Ovis Aries). JAVA. 2009;8(10):1968-1972. [available here]
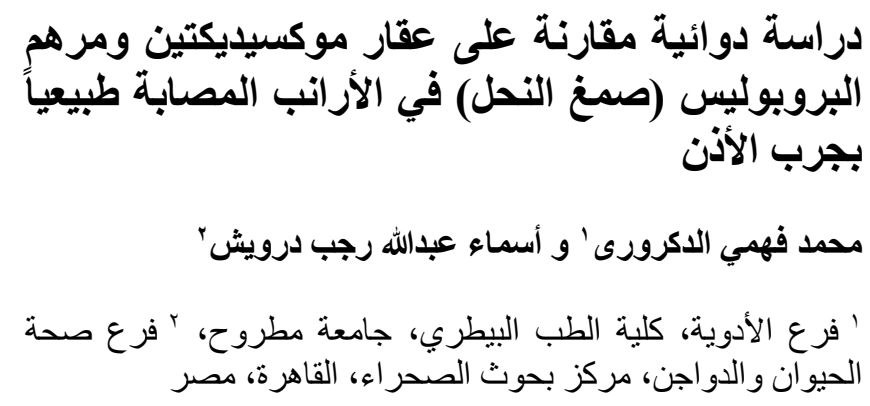

الخلاصة

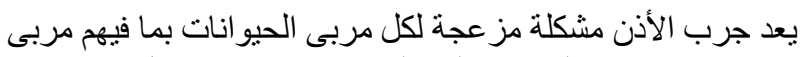

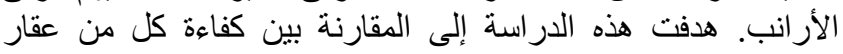

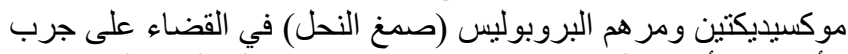

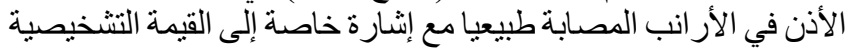

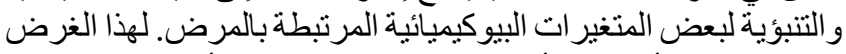

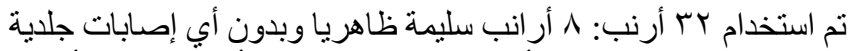

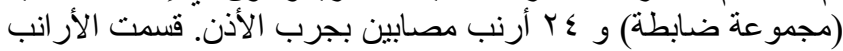

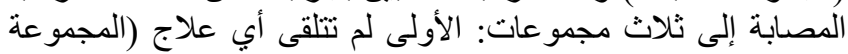

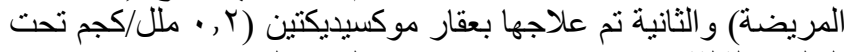

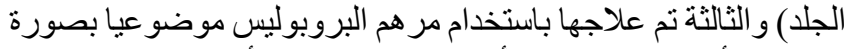

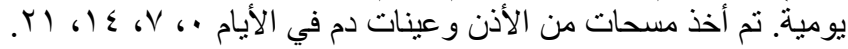
تم فحص المسحات بالميكرسكوب وتقدير المتغيرات البئ البيوكيميائية

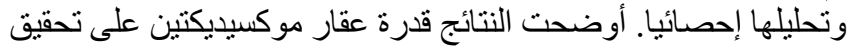

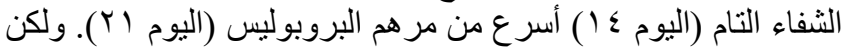

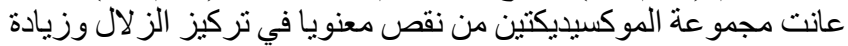

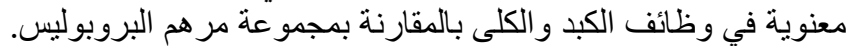
كما حققت وظائف الكبد و الكلى و الكروتيزول قيم جيدة من المساحة تحت المنحنى، الحساسية، المعنوية، نسب الاحتمالية، القيم التبؤية الموجية ونية

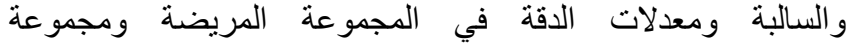

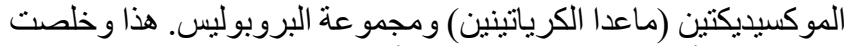

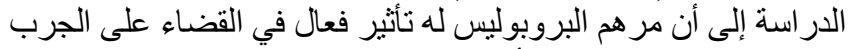

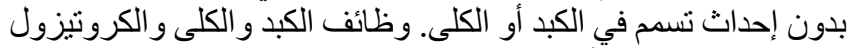
كو اشف جيدة يمكن أن تساعد في تشخيص الجرب أن وابد والتبؤ باستجابة الحيوان لخطط علاجه. 